\title{
Aspartic Hydroxamate Resistance and Asparaginase Regulation in the Fungus Aspergillus nidulans
}

\author{
By C. DRAINAS, J. R. KINGHORN AND J. A. PATEMAN \\ Department of Genetics, University of Glasgow, Glasgow GI I 5JS, Scotland
}

(Received 3I August 1976)

\begin{abstract}
SUMMARY
Eleven mutants resistant to a toxic analogue of asparagine, aspartic hydroxamate, have been isolated; they are allelic and map at the $a h r A$ locus. These mutations result in low or non-detectable asparaginase activity. $a h r A$ mutations are recessive for asparaginase activity and aspartic hydroxamate resistance. The $a h r A$ locus is in linkage group VIII and is loosely linked with $a b a A, p a l B, u Z 9$ and chaA. Asparaginase activity was measured by the formation of aspartic hydroxamate from asparagine and hydroxylamine. The $K_{\mathrm{m}}$ values of asparaginase for asparagine and hydroxylamine are 0.6 and $8.3 \mathrm{~mm}$ respectively. Minimum asparaginase activity is present in cells grown on ammonium or glutamine. Maximum asparaginase activity is present in wild-type cells grown on ammonium and then held in nitrogen-free medium for $3 \mathrm{~h}$. Derepression from this ammonium repression requires protein synthesis. A number of different types of ammonium-repressed and of ammonium-derepressed mutants have abnormal regulation of asparaginase activity.
\end{abstract}

\section{INTRODUCTION}

L-Asparaginase (L-asparagine amidohydrolase EC. 3.5. I . I) has been extensively investigated since it was found that asparaginase from certain bacteria and fungi including Aspergillus has anti-tumour activity (Kidd, I953; Mashburn \& Wriston, I963, I964; Capizzi, Bertino \& Handschumacher, 1970; De-Angeli et al., 1970). Although a wealth of information has accumulated about the biochemistry and immunology of asparaginase, very little is known about its genetics and regulation. The present study deals with certain aspects of the genetics of asparaginase and its regulation in the simple eukaryote Aspergillus nidulans.

Although the normal function of asparaginase is to deaminate asparagine, producing aspartate and ammonium, it can also catalyse the conversion of aspartic hydroxymate to asparagine and hydroxylamine, and vice versa (DeGroot \& Lichtenstein, I960 $a, b$; Ehrman, Cedar \& Schwartz, I97I). Aspartic hydroxamate is extremely toxic for many microorganisms, due to the production of hydroxylamine by the catalytic action of asparaginase. Our studies reveal that mutations in the locus ahr $A$ lead to resistance to aspartic hydroxamate and partial or complete loss of asparaginase activity.

Ammonium represses a number of systems in $A$. nidulans (for review, see Pateman \& Kinghorn, 1976). These include nitrate reductase (Pateman \& Cove, 1967), hypoxanthine dehydrogenase (Scazzocchio \& Darlington, 1968), extracellular protease (Cohen, 1972), acetamidase and formamidase (Hynes, I970; Hynes \& Pateman, 1970), glutamate uptake (Kinghorn \& Pateman, 1972; Pateman, Kinghorn \& Dunn, 1974) and urea uptake (Dunn \& Pateman, 1972). Evidence is presented that ammonium also controls asparaginase activity and that this control involves protein synthesis. 


\section{METHODS}

Chemicals. All chemicals were obtained from commercial sources. DL-Aspartic acid- $\beta$ hydroxamate (aspartic hydroxamate) was obtained from Sigma and was kept at $4{ }^{\circ} \mathrm{C}$. The nitrogen sources used were kept as sterile I $\mathrm{M}$ stock solutions at $4{ }^{\circ} \mathrm{C}$ and used in growth tests at a final concentration of ro mM.

Media. Complete medium (CM) and minimal medium (MM) used for genetic analysis were those described by Pontecorvo et al. (1953). Nitrogen-less minimal medium ( $-\mathrm{N}$ medium) used for growth tests was that described by Cove (I966).

Strains and genetic analysis. The genetic techniques employed were those described by Pontecorvo et al. (1953) and McCully \& Forbes (1965). The strains used were as follows: biAI, a translocation-free biotin auxotroph (Glasgow no. 05I) as wild type; MSE master strain (Glasgow no. 95) for use in haploidization (McCully \& Forbes, 1965); meaA8, a methylammonium-resistant, ammonium-derepressed mutant (Arst \& Cove, 1969; Arst \& Page, 1973); DER-3, an ammonium-derepressed mutant (Pateman et al., 1973; Kinghorn \& Pateman, I973); $\operatorname{tam}^{\mathrm{r}}{ }^{\mathrm{I}}$ I9, a partially ammonium-repressed mutant (Kinghorn \& Pateman, 1975); $\operatorname{tam} A^{\mathrm{r}} 50$, a completely repressed mutant that grows only on ammonium as nitrogen source (Pateman \& Kinghorn, 1975,1976$)$; $\operatorname{tam}^{\mathrm{d}}{ }^{\mathrm{I}} \mathrm{I}$, an ammonium-derepressed mutant (Pateman \& Kinghorn, I975, 1976); niaDI7 (Glasgow no. or26), a mutant lacking nitrate reductase (Pateman \& Cove, I967); and nirAI (Glasgow no. oI 28), a mutant lacking nitrate reductase and nitrite reductase (Pateman \& Cove, 1967). A more comprehensive discussion of the characteristics of the ammonium control mutants is given by Pateman \& Kinghorn (1976). For details of other markers and the Aspergillus nidulans linkage map see Clutterbuck (1974) and Clutterbuck \& Cove (1974).

Isolation of mutants. Wild-type cells do not grow on $-\mathrm{N}$ medium plus $0.3 \mathrm{~mm}$-aspartic hydroxamate plus Io mM-nitrate or on $-\mathrm{N}$ medium plus $0 \cdot \mathrm{I}$ mM-aspartic hydroxamate plus Io mM-alanine as nitrogen source. Resistant (on aspartic hydroxamate) mutants were isolated by plating $N$-methyl- $N^{\prime}$-nitro- $N$-nitrosoguanidine (NTG)-treated biAI wild-type conidia (Adelberg, Mandel \& Chen, 1965) on $-\mathrm{N}$ medium supplemented with Io mMnitrate or alanine as nitrogen source and aspartic hydroxamate. Growing colonies were purified by streaking on complete medium and re-tested on $-\mathrm{N}$ medium plus $10 \mathrm{mM}$ nitrate plus various concentrations of aspartic hydroxamate. Strongly-resistant mutants were isolated on 0.3 to $\mathrm{I} \cdot 5 \mathrm{mM}$-aspartic hydroxamate, while weakly-resistant mutants were isolated on 0.3 to $0.5 \mathrm{~mm}$-aspartic hydroxamate.

Growth of mycelium and extract preparation for asparaginase assays. Cells were grown on $-\mathrm{N}$ medium supplemented with the desired nitrogen source in shaken flask cultures at $30^{\circ} \mathrm{C}$, essentially as described by Cove (I966). The mycelium was harvested through a cheese cloth, washed with distilled water, pressed dry using high-dry paper towels, and weighed. For maximum asparaginase activity the mycelium was grown on $10 \mathrm{~mm}$-ammonium for $17 \mathrm{~h}$ and transferred to nitrogen-free conditions ( $-\mathrm{N}$ medium) for $3 \mathrm{~h}$. The mycelium was extracted by grinding $0.5 \mathrm{~g}$ of pressed dry mycelium in a cold mortar containing $5 \mathrm{ml}$ $0.5 \mathrm{M}$-Tris/HCl buffer $(\mathrm{pH} 7 \cdot 2)$ plus acid-washed sand. The extract was centrifuged at $20000 \mathrm{rev} . \mathrm{min}^{-1}$ for $20 \mathrm{~min}$ in a Beckman Ultracentrifuge at about $4{ }^{\circ} \mathrm{C}$. The supernatant was kept cold in ice and used for the enzyme assays.

Asparaginase assays. The reaction mixture was as follows: $1 \cdot 5 \mathrm{ml} 20 \mathrm{mM}-\mathrm{Tr}$ s $/ \mathrm{HCl}$ buffer (pH 8);0.2 $\mathrm{ml} \mathrm{I00} \mathrm{mM} \mathrm{stock} \mathrm{asparagine} \mathrm{solution} \mathrm{(final} \mathrm{concentration} \mathrm{Io} \mathrm{mM);} 0.2 \mathrm{ml} \mathrm{I} \mathrm{M}$ stock hydroxylamine solution (final concentration $100 \mathrm{mM}$ ); and $0 . \mathrm{I} \mathrm{ml}$ cell extract; total volume $2 \mathrm{ml}$. The reaction mixture was incubated in a water bath at $37^{\circ} \mathrm{C}$. After $30 \mathrm{~min}$ 
$0.5 \mathrm{ml}$ ferric chloride reagent $\left[10 \%(\mathrm{w} / \mathrm{v}) \mathrm{FeCl}_{3}\right.$ plus $5 \%(\mathrm{w} / \mathrm{v})$ trichloroacetic acid in $0.66 \mathrm{M}$ $\mathrm{HCl}$ ] was added. The reaction between the aspartic hydroxamate produced and $\mathrm{FeCl}_{3}$ yielded a brown coloration whose absorption at $500 \mathrm{~nm}$ was measured in a Pye Unicam SPI 800 spectrophotometer. The enzyme activity was expressed as nmol substrate formed $\min ^{-1}$ (mg protein $)^{-1}$. This aspartyl transferase activity of asparaginase was correlated with the ammonium production determined by nesslerization (Imada et al., I973) and aspartic acid production estimated quantitatively by paper chromatography (unpublished).

Protein determination. All protein determinations were carried out by the procedure of Lowry et al. (I95I).

\section{RESULTS}

Toxicity of aspartic hydroxamate on various nitrogen sources

The wild type was sensitive at concentrations greater than $0.3 \mathrm{~mm}$-aspartic hydroxamate with urea, proline or nitrate as the sole nitrogen source. It was sensitive at concentrations greater than $0.5 \mathrm{~mm}$-aspartic hydroxamate with glutamine as sole nitrogen source. With alanine, aspartate or glutamate as the nitrogen source, aspartic hydroxamate was toxic at even the lowest concentration used, $0.1 \mathrm{mM}$. In contrast, ammonium protected against any concentration of the toxic analogue; the wild type grew even on Io mM-aspartic hydroxamate in the presence of ammonium. Asparagine also protected against the toxicity of aspartic hydroxamate at concentrations up to $3 \mathrm{~mm}$.

\section{Isolation and resistance properties of ahr A mutants}

Eleven mutants designated $a h r A$ (aspartic hydroxamate resistance) were isolated on the basis of resistance to the toxic analogue. The mutant $a h r A_{3}$ was characterized as weakly resistant because it could not grow on concentrations of aspartic hydroxamate greater than $0.5 \mathrm{~mm}$ or $0.3 \mathrm{~mm}$ if the nitrogen source was nitrate or alanine respectively. All the other mutants were characterized as strongly-resistant because of their ability to grow on high concentrations of aspartic hydroxamate. The mutant $a h r A 2$ was resistant at any concentration of aspartic hydroxamate tested; $a h r A I$ was not resistant at concentrations greater than $5 \mathrm{mM}$ (Fig. I). The resistance of the mutants was reduced if aspartate, glutamate or alanine was used as nitrogen source (Figs I and 2). The $a h r A$ mutants were not resistant to hydroxylamine, showing that they are defective in the production rather than the metabolism of hydroxylamine. ahr $A$ mutations are recessive with respect to resistance to the wild-type allele in heterozygous diploids since the $\operatorname{ahr} A I / a h r A^{+}, \operatorname{ahr} A 2 / a h r A^{+}, a h r A 3 / a h r A^{+}$, ahr $A 4 / a h r A^{+}$diploids were sensitive to aspartic hydroxamate (Figs I and 2). The heterozygous diploid $a h r A 2 / a h r A 3$ was resistant on aspartic hydroxamate with a phenotype intermediate between those of the haploid strains since it was resistant at I $\mathrm{mM}$ and sensitive at I.5 mM-aspartic hydroxamate.

\section{Growth properties of ahrA mutants}

$a h r A$ mutants grew like the wild type with ammonium, aspartate, asparagine, glutamate or glutamine as the sole nitrogen source and aspartate, asparagine, glutamate or glutamine as the sole carbon source.

\section{Genetic characterization of the ahrA mutants}

The haploidization of the diploids $a h r A I / \mathrm{MSE}, a h r A 2 / \mathrm{MSE}, a h r A_{3} / \mathrm{MSE}$ and $a h r A_{4} / \mathrm{MSE}$ revealed linkage with the marker riboB of the MSE strain, indicating that the $a h r A$ gene is located in linkage group VIII. All the $a h r A$ mutants were crossed to each other and no 


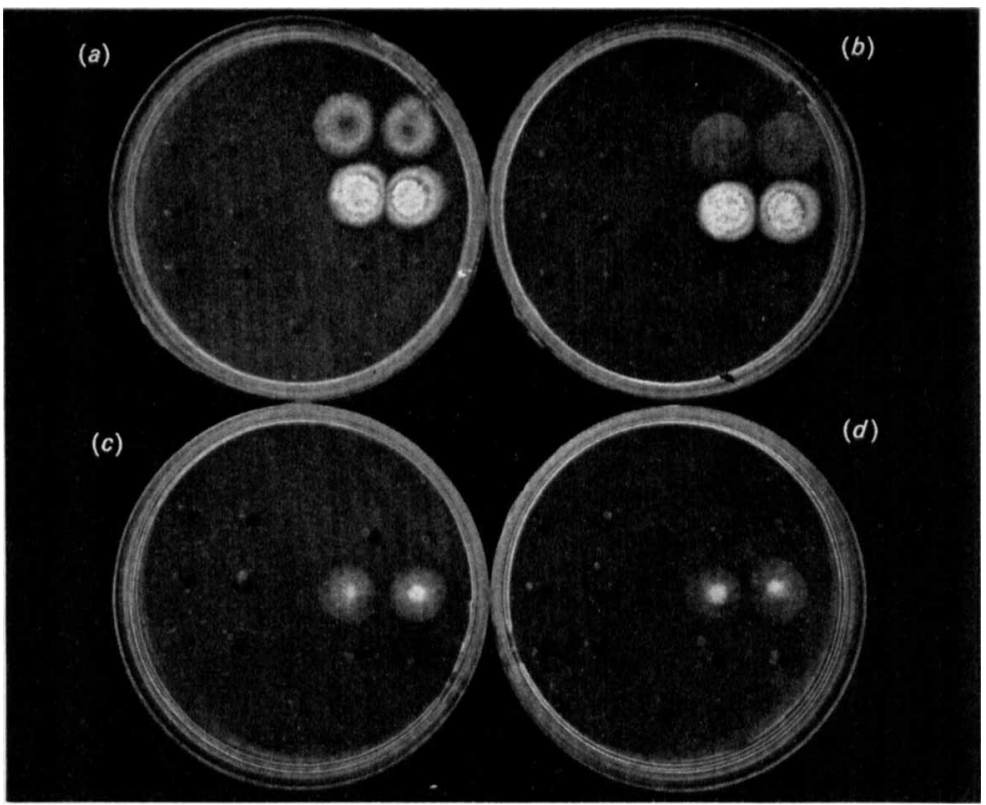

Fig. I. Difference in aspartic hydroxamate (AH) resistance between $a h r A I$ and $a h r A z$ mutants. Nitrogen-free medium was supplemented with $(a)$ Io mM-nitrate plus $5 \mathrm{mM}-\mathrm{AH},(b)$ Io mM-nitrate plus Io mM-AH, (c) Io mM-alanine plus $5 \mathrm{~mm}-\mathrm{AH},(d)$ IO mM-alanine plus $10 \mathrm{~mm}$-AH. Strains were tested in duplicate: top right, $a h r A I$; centre right, $a h r A 2$; other (sensitive) strains were heterozygous diploids of the ahr $A$ mutants and the wild type. The ahrAI mutant grew poorly on nitrate plus Io $\mathrm{mM}-\mathrm{AH}$ and was sensitive on alanine plus 5 or $10 \mathrm{mM}-\mathrm{AH}$.

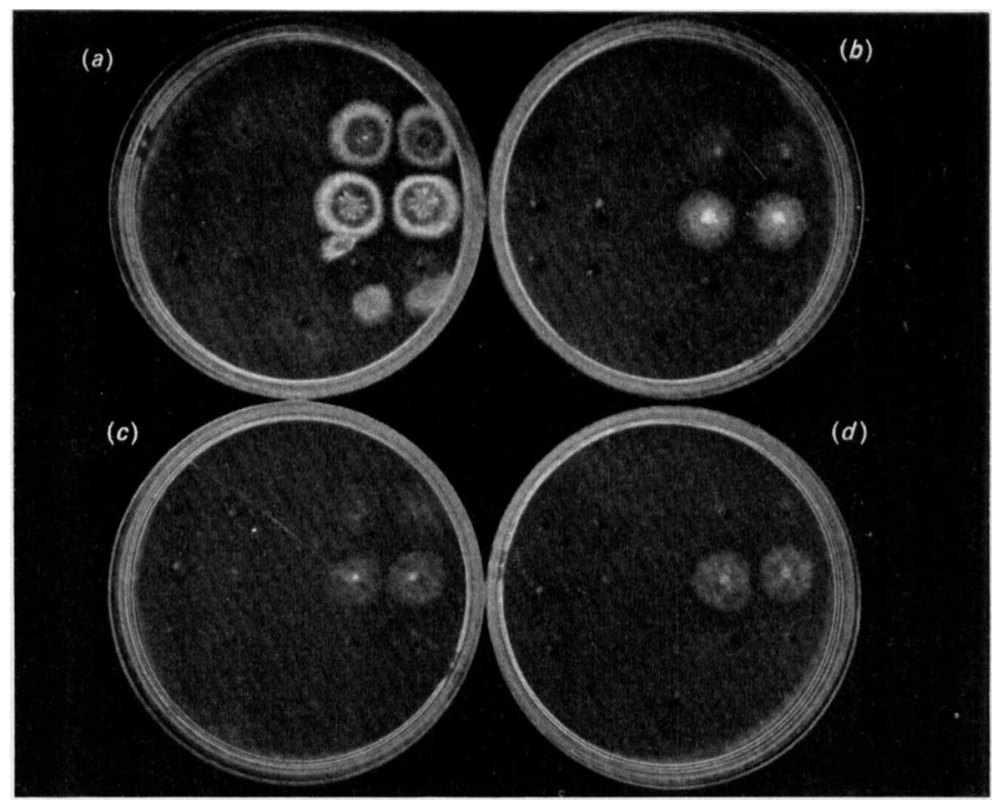

Fig. 2. Reduced resistance of the $\operatorname{ahr} A$ mutants with alanine, glutamate or aspartate. Nitrogen-free medium was supplemented with $3 \mathrm{~mm}$-aspartic hydroxamate plus (a) Io mM-nitrate; (b) Io mMalanine, (c) ro mm-aspartate, $(d)$ Io mm-glutamate. Mutants were arranged on the plates as in Fig. 1. 
Table I. Asparaginase activity of wild-type and ahrA haploid and heterozygous diploid strains

\begin{tabular}{|c|c|c|}
\hline Strains & $\begin{array}{c}\text { Asparaginase activity } \\
{\left[\mathrm{nmol} \mathrm{min}^{-1}(\mathrm{mg} \text { protein })^{-1}\right]}\end{array}$ & $\begin{array}{l}\text { Percentage of maximum } \\
\text { activity in wild type }\end{array}$ \\
\hline$a h r A^{+}$ & I 200 & 100 \\
\hline$a h r A^{+} / a h r A^{+}$ & 1320 & 110 \\
\hline$a h r A I$ & $<5$ & 0 \\
\hline$a h r A r / a h r A^{+}$ & 640 & 53 \\
\hline$a h r A 2$ & $<5$ & 0 \\
\hline$a h r A 2 / a h r A^{+}$ & 630 & 52 \\
\hline$a h r A_{3}$ & 420 & 35 \\
\hline$a h r A 3 / a h r A^{+}$ & 990 & 82 \\
\hline$a h r A 4$ & $<5$ & 0 \\
\hline$a h r A 4 / a h r A^{+}$ & 690 & 57 \\
\hline$a h r A 2 / a h r A_{3}$ & 230 & 18 \\
\hline
\end{tabular}

Table 2. Wild-type asparaginase activity with various nitrogen sources

$\begin{array}{lcc}\text { Nitrogen source (10 mM) } & \text { No treatment } & \begin{array}{c}\text { Transferred to } \\ - \text { N medium for } 3 \text { h }\end{array} \\ \text { Alanine } & 250 & 500 \\ \text { Ammonium } & <5 & 1200 \\ \text { Aspartate } & 250 & 225 \\ \text { Asparagine } & 100 & 750 \\ \text { Glutamate } & 200 & 230 \\ \text { Glutamine } & <5 & 900 \\ \text { Nitrate } & 50 & 800 \\ \text { Nitrite } & <5 & 950 \\ \text { Urea } & 173 & 850\end{array}$

recombinants were obtained in approximately 500 progeny from each cross. The mutants $a h r A I, a h r A z$ and $a h r A 3$ did not complement each other in heterozygous diploids. The $a h r A$ locus recombined freely with the markers $f w$, $f a c B, \operatorname{riboB}$, niaD and nir $A$; it is $23.3 \pm 2.9 \mathrm{cM}$ from $a b a A$ and $13.4 \pm 2.3 \mathrm{cM}$ from palB on linkage group VIII.

\section{Asparaginase activity}

The strongly-resistant $a h r A$ mutants had no detectable asparaginase activity. The weakly resistant $a h r A_{3}$ had about $35 \%$ of the haploid wild-type activity (Table I). The heterozygous diploids of the mutants $a h r A I, a h r A 2, a h r A 4$ with the wild type possessed about $50 \%$ of the enzyme activity of the homozygous wild-type diploid. The heterozygous diploid of the weakly-resistant $a h r A_{3}$ with the wild type had about $80 \%$ of the wild-type diploid activity. The heterozygous diploid between the strongly-resistant $a h r A z$ and the weakly-resistant $a h r A_{3}$ had about $15 \%$ of the enzyme activity of the diploid wild-type.

\section{Regulation of asparaginase}

Asparaginase activity in wild-type cells with various nitrogen sources is shown in Table 2. Cells grown on ammonium as the sole nitrogen source had undetectable enzyme activity. Cells grown on ammonium and transferred to nitrogen-free conditions for $3 \mathrm{~h}$ had the maximum asparaginase activity. Activity was low or undetectable in cells grown with 


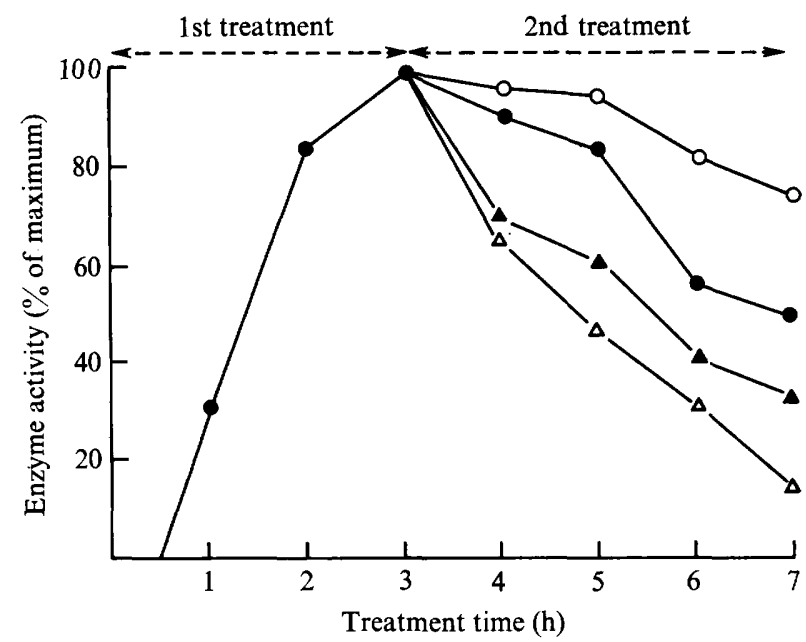

Fig. 3. The effect of ammonium on asparaginase synthesis. Ist treatment: cells were grown on Io mM-ammonium as sole nitrogen source and transferred to nitrogen-free medium. 2nd treatment: e, continuation of nitrogen starvation; $O$, continuation of nitrogen starvation in presence of cycloheximide (Io $\mathrm{mg} \mathrm{ml}^{-1}$ ); $\triangle$, treatment with $10 \mathrm{mM}$-ammonium; $\boldsymbol{\Delta}$, treatment with Io $\mathrm{mm}$ nitrate.

asparagine, urea, glutamine, nitrite or nitrate as the sole nitrogen source. Enzyme activity was increased in cells grown on these nitrogen sources and transferred to nitrogen-free conditions.

The simplest hypothesis to explain these results and the suppression of aspartic hydroxamate toxicity by ammonium is that asparaginase activity is regulated by ammonium repression. Nitrogen starvation results in ammonium derepression and consequent high enzyme activity.

\section{Ammonium repression}

Some aspects of the kinetics of ammonium derepression were investigated. Cells grown on ammonium were transferred to nitrogen-free conditions and their asparaginase activity was determined (Fig. 3). Asparaginase activity could be detected approximately $30 \mathrm{~min}$ after transfer and increased to a maximum at $3 \mathrm{~h}$. After $3 \mathrm{~h}$ the activity decreased. The addition of cycloheximide at the time of transfer (when derepression starts) prevented any increase in enzyme activity, but cycloheximide added to the medium at $3 \mathrm{~h}$ (maximum activity) had less effect on activity. Addition of ammonium at $3 \mathrm{~h}$ (maximum activity) resulted in rapid loss of activity (Fig. 3). When cycloheximide was added at the same time as ammonium, the effect was the same as if ammonium had not been added at all. Nitrate had the same effect as ammonium, but to a lesser extent, and was similarly inhibited by cycloheximide. These results strongly suggest that protein synthesis is necessary for ammonium repression to take place. Ammonium does not inhibit asparaginase activity in vitro (Drainas, unpublished results).

The ammonium-derepressed mutants meaA8, DER-3 and $\operatorname{tam} A^{\mathrm{d}} I$ were not protected by ammonium against the toxicity of aspartic hydroxamate. Furthermore, these mutants had asparaginase activity when grown with ammonium. The partially ammonium-repressed mutant $\operatorname{tam} A^{\mathrm{r}} I 19$ and the completely ammonium-repressed $\operatorname{tam} A^{\mathrm{r}} 50$ had low and undetectable asparaginase activities respectively. 


\section{Affinity of asparaginase for asparagine and hydroxylamine}

The $K_{\mathrm{m}}$ values of asparaginase for asparagine and hydroxylamine were determined as 0.6 and $8.3 \mathrm{~mm}$ respectively. The $K_{\mathrm{m}}$ values of asparaginase were calculated in extracts from the heterozygous diploids $a h r A I /+, a h r A 2 /+, a h r A 3 /+$, the weakly-resistant mutant $a h r A 3$ and the partially ammonium-repressed mutant $\operatorname{tam}^{\mathrm{r}}$ II9. No differences from the wild-type values were found.

\section{DISCUSSION}

Aspartic hydroxamate is apparently toxic for Aspergillus nidulans under certain conditions. The actual toxic agent is not aspartic hydroxamate itself but the hydroxylamine produced by asparaginase activity when this enzyme is present. The $a h r A$ mutants are resistant to aspartic hydroxamate but not to hydroxylamine.

The levels of asparaginase activity show very clear-cut gene dosage effects in various haploids and diploids (Table I). The haploid $a h r A^{+}$and the homozygous diploid $a h r A^{+} / a h r A^{+}$ show similar enzyme levels. The heterozygous diploid $a h r A I / a h r A^{+}$has about $50 \%$ of the enzyme activity of the homozygous wild-type $a h r A^{+} / a h r A^{+}$. The diploid ahrA2/ahrA3 has about $50 \%$ of the enzyme activity of the haploid $a h r A 3$. Clutterbuck (I968) has shown that gene dosage is the same in haploids and diploids in $A$. nidulans, since haploids have about twice as many nuclei per cell as diploids. Therefore the simplest explanation of our results is that gene expression under derepression is limiting with consequent strict gene dosage effects in the various diploids.

All the resistant mutants tested were shown to be allelic and map at the ahr $A$ locus on linkage group VIII. This is likely to be the structural gene locus for an asparaginase activity since all known asparaginase minus mutants map in this gene. There is a spectrum of resistance depending on the nitrogen source and on the concentration of aspartic hydroxamate. Moreover, there is a direct correlation between aspartic hydroxamate resistance and asparaginase activity and this is shown by the weakly-resistant $a h r A_{3}$ mutant which has reduced asparaginase activity.

Paradoxically, ahr $A$ mutants grow like the wild type on asparagine as sole nitrogen or carbon source, indicating that asparagine can be utilized by another system, although aspartic hydroxamate-resistant mutations have not been found at the gene specifying such a system. It is unlikely that growth of ahrA mutants with asparagine is due to residual nonenzymic ammonium formation from asparagine, since the ammonium-repressed control mutant $\operatorname{tam} A^{\mathrm{r}} 50$, which also lacks asparaginase, grows extremely poorly with asparagine as sole nitrogen source indicating that the other system is subject to ammonium repression (Pateman \& Kinghorn, 1976).

The involvement of ammonium in the control of asparaginase is confirmed by the levels of asparaginase activities in ammonium-derepressed mutants. The mutants meaA8, DER-3 and $\operatorname{tam} A^{\mathrm{a}} I$ are not protected by ammonium against the toxicity of aspartic hydroxamate. Asparaginase activity in the presence of ammonium produces hydroxylamine which inhibits the growth of the above mutants. Moreover, these mutants have low activity in the presence of ammonium. The partially repressed mutant $\operatorname{tam} A^{\mathrm{r}}{ }_{119}$ has low asparaginase activity and is resistant to low concentrations of aspartic hydroxamate. Furthermore, the completely repressed mutant $\operatorname{tam} A^{\mathrm{r}} 50$ is completely repressed for asparaginase activity.

There are two main types of explanation for the role of ammonium in the control of asparaginase activity. First, ammonium inactivates asparaginase in vivo and this inactivation, possibly mediated by a protease, needs protein synthesis. Second, ammonium 
represses asparaginase synthesis and the requirement for protein synthesis is due to the ammonium-mediated synthesis of one or more control proteins which block the synthesis of asparaginase.

We thank Mrs E. Dunn, Dr J. Clutterbuck and Mr E. Forbes for helpful discussion. One of us (J.R.K.) thanks the Science Research Council for support (grant no. B/RG/48502).

\section{REFERENCES}

Adelberg, E. A., MANDel, M. \& Chen, G. C. C. (1965). Optimal conditions for mutagenesis by $N$-methyl$N^{\prime}$-nitro- $N$-nitrosoguanidine in Escherichia coli K12. Biochemical and Biophysical Research Communications $18,788-795$.

ARst, H. N. \& COVE, D. J. (1969). Methylammonium resistance in Aspergillus nidulans. Journal of Bacterio$\log y$ 98, I284-I 293.

ARsT, H. N. \& PAGE, M. M. (1973). Mutants of Aspergillus nidulans altered in the transport of methylammonium and ammonium. Molecular and General Genetics 12x, 239-245.

Capizzi, R. L., Bertino, J. R. \& HANDSChumacher, R. E. (1970). L-Asparaginase. Annual Review of Medicine 2r, 433-444.

Clutrerbuck, A. J. (1968). Cell volume per nucleus in haploid and diploid strains of Aspergillus nidulans. Journal of General Microbiology 55, 29I-299.

ClutTerbuCK, A. J. (1974). Aspergillus nidulans. In Handbook of Genetics, vol. 1, pp. 447-5IO. Edited by R. C. King. New York: Plenum Press.

ClUTTERBUCK, A. J. \& Cove, D. J. (1974). Linkage map of Aspergillus nidulans. In Handbook of Microbiology. Vol. IV. Microbial Metabolism, Genetics and Immunology, pp. 665-676. Edited by A. I. Laskin and H. A. Lechevalier. Cleveland, Ohio: C.R.C. Press.

COHEN, B. L. (1972). Ammonium repression of extracellular protease in Aspergillus nidulans. Journal of General Microbiology 71, 293-299.

Cove, D. J. (1966). The induction and repression of nitrate reductase in the fungus Aspergillus nidulans. Biochimica et biophysica acta $113,5 \mathrm{I}-56$.

De-Angeli, L. C., Pocochani, F., Russi, S., Tonolo, A. \& Zurita, V. E. (1970). Effect of L-asparaginase from Aspergillus terreus on ascites sarcoma in the rat. Nature, London 225, 549-550.

DeGroot, N. \& Lichtenstein, N. (1960a). The action of mammalian liver enzyme preparations on asparagine and asparagine derivatives. Biochimica et biophysica acta 40, 92-98.

DeGroot, N. \& Lichtenstern, N. ( $1960 \mathrm{~b}$ ). The action of Pseudomonas fluorescens extracts on asparagine and asparagine derivatives. Biochimica et biophysica acta 40, 99-110.

Dunn, E. \& Pateman, J. A. (1972). Urea and thiourea uptake in Aspergillus nidulans. Heredity 29, 129.

Ehrman, M., Cedar, H. \& Schwartz, J. H. (1971). L-Asparaginase II of Escherichia coli. Journal of Biological Chemistry 246, 88-94.

HYNES, M. J. (1970). Induction and repression of amidase enzymes in Aspergillus nidulans. Journal of Bacteriology 103, 482-487.

Hynes, M. J. \& PATEMAN, J. A. (1970). The genetic analysis of regulation of amidase synthesis in Aspergillus nidulans, I \& II. Molecular and General Genetics 108, 97-1 16.

Imada, A., Igarasi, S., NAKAhAMA, K. \& IsONo, M. (I973). Asparaginase and glutaminase activities of micro-organisms. Journal of General Microbiology 76, 85-99.

KIDD, J. C. (1953). Regression of transplanted lymphomas induced in vivo by means of normal guinea pig serum (I and II). Journal of Experimental Medicine 98, 565-606.

Kinghorn, J. R. \& PATEMAN, J. A. (1972). Regulation of glutamate transport in Aspergillus nidulans. Heredity 29, 128

KinghoRN, J. R. \& PATEMAN, J. A. (1973). A new class of mutants affecting ammonium regulation and methylammonium resistance in Aspergillus nidulans. Heredity 31, 477-478.

KINGHORN, J. R. \& PATEMAN, J. A. (1975). Studies of partially repressed mutants at the tamA and are $A$ loci in Aspergillus nidulans. Molecular and General Genetics 140, 137-147.

Lowry, O. H., Rosebrough, N. J., Farr, A. L. \& Randall, R. J. (195I). Protein measurement with the Folin phenol reagent. Journal of Biological Chemistry 193, 265-275.

MCCULLY, K. S. \& FoRBES, E. (1965). The use of $p$-fluorophenylalanine with 'master strains' of Aspergillus nidulans for assigning genes to linkage groups. Genetical Research 6, 352-359.

MAshbURN, L. T. \& Wriston, J. C., JR (1963). Tumour inhibitory effect of L-asparaginase. Biochemical and Biophysical Research Communications 12, 50-55.

MASHBURN, I. T. \& WRISTON, J. C., JR (1964). Tumour inhibitory effect of L-asparaginase from Escherichia coli. Arehives of Biochemistry and Biophysics 105, 45I-452. 
Pateman, J. A. \& Cove, D. J. (1967). Regulation of nitrate reduction in Aspergillus nidulans. Nature. London 2r5, I734-I737.

Pateman, J. A. \& Kinghorn, J. R. (1975). The tamA locus in Aspergillus nidulans. Heredity $35,27$.

Pateman, J. A. \& KinghoRN, J. R. (1976). Nitrogen metabolism. In Filamentous Fungi, vol. 2, pp. 159-237. Edited by J. E. Smith and D. Berry. London: Edward Arnold.

Pateman, J. A., Kinghorn, J. R., Dunn, E. \& Forbes, E. (1973). Ammonium regulation in Aspergillus nidulans. Journal of Bacteriology II4, 943-950.

Pateman, J. A., Kinghorn, J. R. \& DunN, E. (I974). Regulatory aspects of L-glutamate transport in Aspergillus nidulans. Journal of Bacteriology $\mathbf{1} 19,534-542$.

Pontecorvo, G., Roper, J. A., Hemmons, L. M., MacDonald, K. D. \& Bufton, A. W. J. (I953). The genetics of Aspergillus nidulans. Advances in Genetics 5, I4I-238.

Scazzocchio, C. \& Darlington, A. J. (1968). The induction and repression of the enzymes of purine breakdown in Aspergillus nidulans. Biochimica et biophysica acta 166, 551-568. 